\title{
PENGEMBANGAN MODEL REDUKSI RESIKO DAN ESKALASI KINERJA PEMBIAYAAN MUDHARABAH PADA LEMBAGA KEUANGAN MIKRO SYARI'AH
}

\author{
Siti Maria Wardayati, Nining Ika Wahyuni dan Nur Hisamuddin \\ Fakultas Ekonomi, Universitas Jember \\ maria_unej@yaboo.co.id,ni2ng_ika@yaboo.co.id, bi5am@yaboo.com
}

\begin{abstract}
The development of Islamic financial institutions in Indonesia is very fast even though it is a new institution that all products are new in this Muslim-majority country. This study will test the competence variables account syariah officer and risk of financing in relation to the financing is affecting performance, and will also test the variable business ethics and information asymmetry in relation to risk and financial performance. Sample of this research is Islamic Microfinance Institutions in Jember and Bondowoso with respondent managers and leaders Sharia Micro finance Institutions using primary data obtained through questionnaires. This study used a quantitative approach and the data processing using Partial Least Square (PLS). Final output of this research is the development of arisk reduction model of financing is an attempte scalation of financing performance.
\end{abstract}

Keywords: Mudharabah Financing, Islamic Business Ethics, Information Asymmetry, and Performance

\begin{abstract}
Abstrak
Perkembangan lembaga keuangan syariah di Indonesia sangat pesat meskipun merupakan lembaga baru yang semua produknya tergolong baru di negara yang mayoritas Islam ini. Penelitian ini akan menguji variabel kompetensi account officer syariah dan risiko pembiayaan yang mempengarubi kinerja pembiayaan mudharabah, dan juga menguji variabel etika bisnis islami dan informasi asimetri dalam kaitannya dengan risiko dan kinerja pembiayaan mudharabah. Sampel dari penelitian ini adalah Lembaga Keuangan Mikro Syariah di Jember dan Bondowoso dengan responden manajer dan pemimpin LKMS dengan menggunakan data primer yang diperoleh melalui kuesioner. Penelitian ini menggunakan pendekatan kuantitatif dan alat pengolahan data menggunakan Partial Least Square (PLS). Hasil keseluruban penelitian ini adalah signifikan. Hasil akbir dari penelitian ini adalab pengembangan dari model pengurangan risiko pembiayaan mudharabah merupakan eskalasi upaya kinerja pembiayaan tersebut.
\end{abstract}

Kata Kunci: Pembiayaan Mudharabah, Etika Bisnis Islam, Informasi Asimetri, dan Kinerja. 


\section{Pendahuluan}

Pertumbuhan ekonomi suatu negara harus disertai pertumbuhan sector riil di negara tersebut. Guna memperlancar pertumbuhan ekonomi salah satu syaratnya dibutuhkan aliran dana yang lancar. Guna memperlancar aliran ini, dibutuhkan suatu lembaga yang mampu menjadi mobilisator, yang biasa kita sebut dengan lembaga keuangan. Layaknya sebuah jantung lembaga keuangan mengalirkan dana hingga ke unit terkecil. Selain jangkauannya lembaga keuangan juga harus memiliki sistem keuangan yang dapat mendorong kemajuan sektor riil, karena jangan sampai sekor riil dikalahkan oleh sektor financial. Karena pada dasarnya sektor financial hanyalah berfungsi sebagai mediator.

Kemunculan lembaga keuangan syariah di dunia disambut baik oleh masyarakat terkait sistem keuangannya.Dalam hal pembiayaan pola yang digunakan adalah sistem bagi hasil dan sistem non-bagi hasil.Sistem bagi hasil adalah pola yang menjadi coreproduct sekaligus pembeda dari pola pembiayaan yang sering digunakan sekarang ini yakni bunga. Dengan sistem bagi hasil dasar pengenaan biaya modal didasarkan pada penghasilan yang didapat oleh nasabah sehingga aspek keadilan sangat terasa disini, berbeda dengan sistem bunga yang banyak dipakai sekarang ini memberikan banyak beban keuangan terhadap sektor riil. Sistem bagi-hasil diyakini sebagai alat penghapus sistem bunga (Siddiqui, 2005). Karim (2004:195) menjelaskan bahwa kontrak sistem bagi -hasil tidak memberikan kepastian pendapatan baik dari segi jumlah maupun waktu. Jadi dalam kontrak ini return dan timing cash flow-nya tergantung pada kinerja bisnis mudharib (pengelola dana mudharabah).

Perkembangan lembaga keuangan syariah di Indonesia sangat pesat meskipun merupakan lembaga baru yang semua produknya tergolong baru di negara yang mayoritas Islam ini. Dengan jumlah umat islam yang besar dan jumlah unit usaha kecil mikro yang kurang lebih 90\% dari semua total unit usaha yang ada (BPS:2012) sangat memungkinkan lembaga keuangan syariah untuk tumbuh lebih besar lagi. Pola pembiayaan yang efektif dan efisienlah yang dibutuhkan oleh pelaku bisnis mikro, karena masalah utama tidak berkembangnya sector riil menengah dan mikro di Indonesia adalah pendanaan. 
Diharapkan konsep pembiayaan yang dimiliki lembaga keuangan syariah dapat memacu perkembangan sector riil mikro ini. Kemudian dalam prakteknya guna memperlancar aliran dana hingga ke unit mikro sangat dibutuhkan lembaga keuangan mikro yang dapat menjangkau lapisan ekonomi ini. Kehadiran lembaga keuangan mikro syariah sangat membantu. Dengan keunggulan praktik operasional sesuai syariah dan kearifan lokal diharapkan efektif dalam meningkatkan perekonomian secara umum dan merata.

Terkait dengan keunggulan pola bagi hasil, ternyata pembiayaan bagi hasil masih sangat jarang dipakai di dunia termasuk Indonesia. Samad dan Hassan (1999) yang menunjukkan bahwa pembiayaan berdasarkan sistem profit sharingdanjoint venture profit sharing tidak populer di Malaysia disebabkan karena hampir 40\% s/d 70\% bankir kurang pengetahuan dalam menyeleksi proyek bagi hasil yang menguntungkan, mengelola proyek bagi hasil dan mengevaluasi tingkat keuntungan dari suatu proyek. Menurut Karim (2004a:251) resiko pembiayaan bisa timbul karena analisis pembiayaan yang keliru dilakukan karyawan bank syariah. Sehingga dalam penelitian ini akan menguji variabel kompetensi account officier syariah dan risiko pembiayaan mudharabah dalam hubungannya dalam mempengaruhi kinerja pembiayaan mudharabah.

Dengan konsep pembiayaan yang mendasarkan pada kejujuran kedua belah pihak menjadikan pembiayaan mudharabah sangat sulit dijalakan. Informasi asimetri menjadi tantangan utama lembaga keuangan syariah. Ideologi agama Islam dapat bertindak seperti mekanisme insentif untuk mengurangi ketidakefisienan yang berasal dari informasi asimetri and moral hazard (Abdelhamid, 2005). Harri dan Raviv (1990) menguji hubungan antara informasi asimetri dan model keagenan. Temuannya menyimpulkan bahwa munculnya informasi asimetri dapat mempengaruhi besar kecilnya pendapatan investasi yang diperoleh.Berdasarkan penjelasan tersebut menunjukkan bahwa informasi asimetri mempunyai pengaruh terhadap kinerja perusahaan. Studi yang dilakukan oleh Larry (1990) di Amerika menemukan bahwa perusahaan yang komit dengan etika dapat mendongkrak profitabilitas dan pertumbuhan bisnis yang digeluti. Oleh itu penelitian ini juga akan menguji variabel etika bisnis dan informasi asimetri dalam hubungannya dengan 
resiko dan kinerja pembiayaan.

Studi ini dilakukan untuk mengetahui, mengkonfirmasi serta menguji pengaruh kompetensi account officer syariah, etika bisnis Islam terhadap informasi asimetri, resiko pembiayaan mudharabah terhadap kinerja pembiayaan mudharabah pada lembaga keuangan mikro syariah di Jember dan Bondowoso. Studi ini juga dilakukan untuk mengetahui kendala pelaksanaan operasionalisasi pembiayaan mudharabah secara kaffah. Dengan studi ini diharapkan solusi pemecahan masalah pembiayaan mudharabah dapat diketahui sehingga dapat membantu meningkatkan kinerja pembiayaan mudharabah.

\section{Teori Keagenan}

Teori keagenan berkaitan dengan hubungan principal dan agent dengan adanya pemisahan kepemilikan dan pengendalian perusahaan (Jensen and Meckling, 1976). Adanya pemisahan kepemilikan dan pengendalian perusahaan ini akan menyebabkan timbulnya information asymmetry. Khalil menjelaskan agency problem yang dipicu oleh konflik antara prinsipal dan agen juga terjadi pada kontrak mudharabah dan bahkan masalahagency pada kontrak mudharabah cenderung lebih besar dibanding dengan kontrak modal atau pun hutang lainnya. Keadaan ini juga disebabkan karena struktur perusahaan yang dalam hubungan kontraktual dari mudharabah adalah berbeda dan lebih komplek dibanding dengan kontrak keuangan lainnya (Manzilati, 2004). Jika pihak-pihak yang terlibat dalam transaksi (kontrak) bisnis seperti kontrak mudharabah memiliki keyakinan akan kehidupan akherat yang abadi dan sejahtera maka akan mempengaruhi perilaku pihak-pihak yang terlibat untuk selaku bertindak (beretika) secara Islami dan menghindari tindakan yang merugikan satu sama lain. Hal ini sesuai dengan teori enterprise syariah yang mengfungsikan agama (syariah) sebagai suatu hal yang menyatu dalam agency theory, maka akan memunculkan batasan perilaku berupa kode etik bagi pihak-pihak yang terlibat dalam dimensi hubungan kontrak antara prinsipal dan agen seperti halnya antara bank Islam dengan mudharib dalam pembiayaan mudharabah. 
Berdasarkan penjelasan teori enterprise syariah mengenai perlunya pihak-pihak yang terlibat dalam kegiatan bisnis supaya beretika bisnis islami seperti halnya pada kontrak produk pembiayaan mudharabah bank syariah maka perlu dilakukan kajian penelitian tentang etika bisnis islami bagi mudharib, yang menjalankan bisnis yang didanai produk pembiayaan mudharabah bank umum syariah. Oleh karena itu dalam penelitian ini etika bisnis islami bertindak sebagai sebuah variabel penelitian yang akan diteliti. Dengan demikian variabel etika bisnis islami diturunkan dari teori enterprise syariah. Teori enterprise syariah sebagai grand theory yang memayungi variabel etika bisnis islami.

\section{Kompetensi Account Officer Syariah dan Resiko Pembiayaan Mudharabah}

Pemberian pinjaman berdasarkan sistem bagi-hasil memerlukan kewaspadaan yang lebih tinggi dari pihak bank. Sugiarto (2004) menjelaskan bahwa kualitas manajemen bank sangat diperlukan untuk memperkecil terjadinya resiko-resiko bank khususnya operational risk.

Manajemen bank harus memiliki keahlian dan kompetensi untuk meminimalisir resiko-resiko yang dihadapi oleh suatu bank, sehingga segala macam resiko yang berpotensi untuk muncul dapat diantisipasi dari sejak awal dan dicarikan cara penanggulangannya (Sugiarto, 2004). Dalam mengelola resiko yang dihadapi oleh bank, maka manajemen bank harus dibekali dengan keahlian dan kompetensi yang mencukupi sehingga dalam tugasnya sehari-hari para manajer resiko tersebut mampu mengukur dan meminimalisir resiko-resiko yang muncul dari kegiatan usaha banknya. Keahlian dan kompetensi mengenai manajemen resiko tersebut sangat diperlukan untuk mengelola resiko yang akan dihadapi oleh bank tersebut dalam menjalankan kegiatan usahanya (Sugiarto, 2004). Tanpa sumber daya manusia yang kompeten, tidak mungkin suatu bank menjadi lebih maju dalam penerapan manajemen resiko (Fardiansyah, 2006:32). Masih minimnya sumberdaya manusia yang memahami secara komprehensif segala hal yang berkaitan dengan industri perbankan syariah menyebabkan seringkali terjadi penyimpangan-penyimpangan aktivitas transaksi yang tidak sesuai dengan 
syariah (Baiq, 2005).Berdasarkan penjelasan tersebut, maka hipotesis pertama yang diajukan dalam penelitian ini adalah sebagai berikut.

$\mathrm{H}_{1}$ : Kompetensi account officersyariah berpengaruh terhadap resiko pembiayaan mudharabah.

\section{Kompetensi Account Officer Syariah dan Kinerja Pembiayaan Mudharabah}

Wei and Weidong (2002) menjelaskan bahwa kompetensi adalah pengetahuan, skill dan kemampuan serta karakter yang berhubungan dengan kinerja efektif yang tinggi. Kompetensi mempunyai pengaruh nyata terhadap kinerja. Ismail (2001) mengungkapkan bahwa secara empirik hubungan yang signifikan antara sumberdaya manusia dengan pengukuran kinerja baik pada perusahaan yang berbasis pengetahuan tinggi maupun rendah. Riset yang dilakukan oleh Iqbal (2001)menyimpulkan bahwa skill yang tinggi sangat dibutuhkan dalam menangani bermacam-macam dan kompleknya transaksi pembiyaan. Menurut Ibrahim (2004) rendahnya pengembangan bank Islam disebabkan karena ketiadaan keahlian sumber daya manusia di perbankan syariah. Bank Indonesia (2002) mengungkapkan bahwa kurangnya kompetensi sumber daya insani menyebabkan rendahya pembiayaan sistem bagi-hasil.

Menurut Thaher dan Abdul (2004), faktor sumeber daya bankirs (account officers) yang menyebabkan nasabah perbankan syariah seringkali pindah ke bank lain karena menganggap pelayanan dari pihak perbankan syariah kurang profesional. Fry and Matherly (2003) mengungkapkan bahwa banyak model kinerja mengakui secara fundamental bahwa sumberdaya manusia berperanan mempengaruhi proses organsisasi dan kinerja. Berdasarkan penjelasan tersebut, maka hipotesis kedua yang diajukan dalam penelitian ini adalah sebagai berikut.

$\mathrm{H}_{2}$ : Kompetensi account officersyariah berpengaruh terhadap kinerja pembiayaan mudharabah. 


\section{Etika Bisnis Islami dan Informasi Asimetri}

Kontrak pembiayaan bagi-hasil (mudharabah) akan berjalan jika terdapat mekanisme keterbukaan (transparansi), kejujuran, keamanahan dan keadilan dari mudharib. Namun menurut Supomo praktek perusahaan sangat sulit dan tidak mudah untuk menerapkan konsep representation faithfulness. Dalam kondisi ini kemudian muncullah masalah ketidakseimbangan informasi (Ludigdo dan Abdurahman, 2004). Ketidakseimbangan informasi (information asymmetry) menurut Scoot (2006:11) terdiri atas dua tipe utama, yaitu adverse selection dan moral hazard. Atas kondisi ini maka beberapa penelitian yang dikutip oleh Machfoed menunjukkan bahwa manfaat informasi telah diragukan reliabilitasnya dan akuntabilitasnya berkaitan dengan fenomena agency theory (Ludigdo dan Abdurahman, 2004). Agency problem dalam debt contract adalah salah satu pencerminan dari perilaku-perilaku bisnis yang menyimpang dari fitrah manusia sebagai makhluk yang mempunyai kecenderungan berbuat kebajikan. Agama mempunyai pengaruh dalam pembentukan sikap karena agama meletakkan dasar konsep moral dalam diri individu. Agama yang dapat mengembalikan agency theory dalam dimensi yang lebih baik dan humanis.

Joseph (2004) membuktikan bahwa etika bisnis membantu mengatasi moral hazard dan mengurangi biaya keagenan. Sebenarnya, ideologi agama Islam bertindak seperti mekanisme insentif untuk mengurangi ketidakefisienan yang berasal dari informasi asimetri and moral hazard (Abdelhamid, 2005). Berdasarkan penjelasan tersebut, maka hipotesis ketiga yang diajukan dalam penelitian ini adalah sebagai berikut.

$\mathrm{H}_{3}$ : Etika bisnis islami berpengaruh terhadap informasi asimetri

\section{Etika Bisnis Islami dan Kinerja Pembiayaan Mudharabah}

Hasil studi menunjukkan adanya hubungan antara etika dan kinerja. Penelitian Larry (1990) menunjukkan ada hubungan antara etika dan keuntungan perusahaan dalam jangka panjang. Rusyani (2004) mengungkapkan bahwa perusahaan yang tidak perduli pada etika bisnis, maka kelangsungan hidup perusahaan itu akan terganggu dan akan berdampak pula pada kinerja keuangannya. 
Schmidt dan Hunter membuktikan secara empirik bahwa etika karyawan mempengaruhi kinerja pekerjaan.

Riset yang dilakukan oleh DePaul University di tahun 1997, menemukan bahwa perusahaan yang merumuskan komitmen korporat mereka dalam menjalankan prinsip-prinsip etika memiliki kinerja finansial (berdasar penjualan tahunan) yang lebih bagus dari perusahaan lain yang tidak melakukan hal serupa (Iman, 2006). Badroen dkk (2006:15) menjelaskan bahwa etika bisnis merupakan seperangakat nilai tentang baik/buruk, salah/benar, wajar/tidak wajar, layak, tidak layak, halal/tidak halal dalam dunia bisnis berdasarkan pada prisnsip-prinsip moral. Dalam arti lain berarti seperangkat prinsip dan norma dimana para pelaku bisnis harus komit padanya dalam bertransaksi, berperilaku dan berelasi guna mencapai tujuan-tujuan bisnisnya dengan selamat. Berdasarkan penjelasan tersebut, maka hipotesis keempat yang diajukan dalam penelitian ini adalah sebagai berikut.

$\mathrm{H}_{4}$ : Etika bisnis islami berpengaruh terhadap kinerja pembiayaan mudharabah.

\section{Informasi Asimetri dan Resiko Pembiayaan Mudharabah}

Secara teoritis bank Islam menghadapi dua resiko yaitu resiko moral karena rendahnya kejujuran dan integritas sebagian peminjam dana dalam menyampaikan kerugian, dan resiko bisnis yang berasal dari perilaku pasar yang tidak diharapkan (Kazmi, 2004). Karim (2004:202) menegaskan bahwa pembiayaan sistem bagi-hasil mudharabah menuntut saling percaya yang tinggi antara nasabah dengan bank. Kenyataan ini menjadikan pembiayaan yang beresiko tinggi, karena bank akan selalu menghadapi permasalahan information asymmetry. Eisenhardt (1989) menjelaskan bahwa teori keagenan menggunakan tiga asumsi sifat manusia yaitu:

1. manusia pada umumya mementingkan diri sendiri (self interest);

2. manusia memiliki daya pikir terbatas mengenai persepsi masa mendatang (bounded rationality); dan

3. manusia selalu menghindari resiko (risk averse). Berdasarkan asumsi sifat dasar manusia tersebut manajer sebagai manusia akan bertindak opportunistic, yaitu mengutamakan kepentingan 
pribadinya (Haris, 2004).

Elgari (2003) menjelaskan bahwa tidak diragukan bahwa pembiayaan mudarabah dan musyarakah menghadapi resiko tinggi disebabkan karena moral hazard, karena kedua bentuk kontrak ini berhubungan dengan resiko aktivitas komersial yang tergantung pada dapat dipercayatidaknya para nasabah. Standar etika klien lebih rendah dari yang diharapkan sehingga pencapaian tujuan dari investasi yang diinginkan tidak mungkin tercapai.Berdasarkan penjelasan tersebut, maka hipotesis pertama yang diajukan dalam penelitian ini adalah sebagai berikut.

$\mathrm{H}_{5}$ : Informasi asimetri berpengaruh terhadap resiko pembiayaan mudharabah.

\section{Informasi Asimetri dan Kinerja Pembiayaan Mudharabah}

Teori profit-loss sharing menjelaskan bahwa bank Islam pada posisi yang efektif berkat sistem bagi-hasil membuat profitabilitasnya less volatile sepanjang peredaran. Sedangkan bukti empirik menunjukkan bahwa bank Islam memang sangat menguntungkan daripada bank umum. Hal ini didukung oleh riset Kazarian dalam Andrew (2004) menemukan bahwa bank Islam di Mesir sangat efisien dan profitable. Hassoune (2002) membuktikan bahwa profitabilitas bank Islam lebih baik daripada bank umum. Keunggulan kinerja bank syariah di atas bank konvensionel sebagaimana dijelaskan di atas memiliki persyaratan jika pada kondisi ideal yaitu keadaan dimana informasi asimetri antara bank syariah dan pengelola dana (mudharib) sangat kecil. Sebagaimana dijelaskan oleh Hassan (2006) bahwa equity contract (mudharabah dan musyarakah) lebih baik daripada debt contract dalam ekonomi apabila informasi asimetri akibat adverse selection dan moral hazard lebih kecil.

Mirakhor dan Iqbal (2004) menjelaskan bahwa kontrak mudharabah dapat menciptakan permasalahan moralhazard karena bank Islam tidak mampu mendesak usaha dan tindakan pengusaha untuk mengoptimalkan pendapatan dan para pengusaha memiliki insentif melaporkan laba rendah dan melaporkan biaya tinggi. Berdasarkan penjelasan tersebut, maka hipotesis keenam yang diajukan dalam penelitian ini adalah sebagai berikut. 
$\mathrm{H}_{6}$ : Informasi asimetri berpengaruh terhadap kinerja pembiayaan mudharabah.

Resiko Pembiayaan Mudharabah dan Knerja Pembiayaan Mudharabah

Hubungan pengaruh antara resiko dengan kinerja dijelaskan oleh Gizycki (2001)bahwa return on asset (ROA) suatu bank dipengaruhi oleh resiko kredit dan semakin tinggi resiko telah mengurangi profitabilitas bank. Hubungan antara resiko dengan kinerja bank syariah dijelaskan dalam cetak biru perbankan syariah Indonesia.

Menurut Arifin (2006:121) manajemen bank harus secara simultan mempertimbangkan berbagai resiko yang akan berpengaruh pada perubahan tingkat laba yang diperoleh. Karena resiko kredit, terjadi ketidakpastian net-income dan market value of equity disebabkan karena tidak ada pembayaran dan penundaan pembayaran baik pokok maupun bunga (Ahmed:2005). El-Biraika (2001) menjelaskan bahwa sistem bagi-hasil meningkatkan finance stability melalui pengurangan resiko dan mengeliminasi konflik kepentingan antara peminjam dan pemberi pinjaman membuat perbankan Islam lebih efisien sebagai lembaga intermediasi.

Khan (2001) mengungkapkan keberlangsungan dan pertumbuhan bank Islam sebagian bergantung pada kemampuan bank mengelola resiko berkaitan dengan bisnis bank. Hal ini juga ditegaskan oleh Syed Jaafar Aznan bahwa kesuksesan perbankan syariah pada masa depan sangat tergantung kepada efektivitas bank syariah dalam mengelola resikonya (Boediono, 2005). Keberlangsungan dan pertumbuhan bank Islam sebagian bergantung pada kemampuan bank mengelola resiko berkaitan dengan bisnis bank (Khan, 2001). Hasil penelitian Sumarna (2007) mengungkapkan bahwa semua variabel resiko bank mempengaruhi kinerja bank yang diwakili oleh return on equity. Berdasarkan penjelasan tersebut, maka hipotesis ketujuh yang diajukan dalam penelitian ini adalah sebagai berikut.

$\mathrm{H}_{7}$ : Resiko pembiayaan mudharabah mempengaruhi kinerja pembiayaan mudharabah. 


\section{Model Penelitian}

Model yang dibentuk dalam penelitian ini yang diperoleh dari kajian teori dan pengembangan hipotesis adalah sebagai berikut :

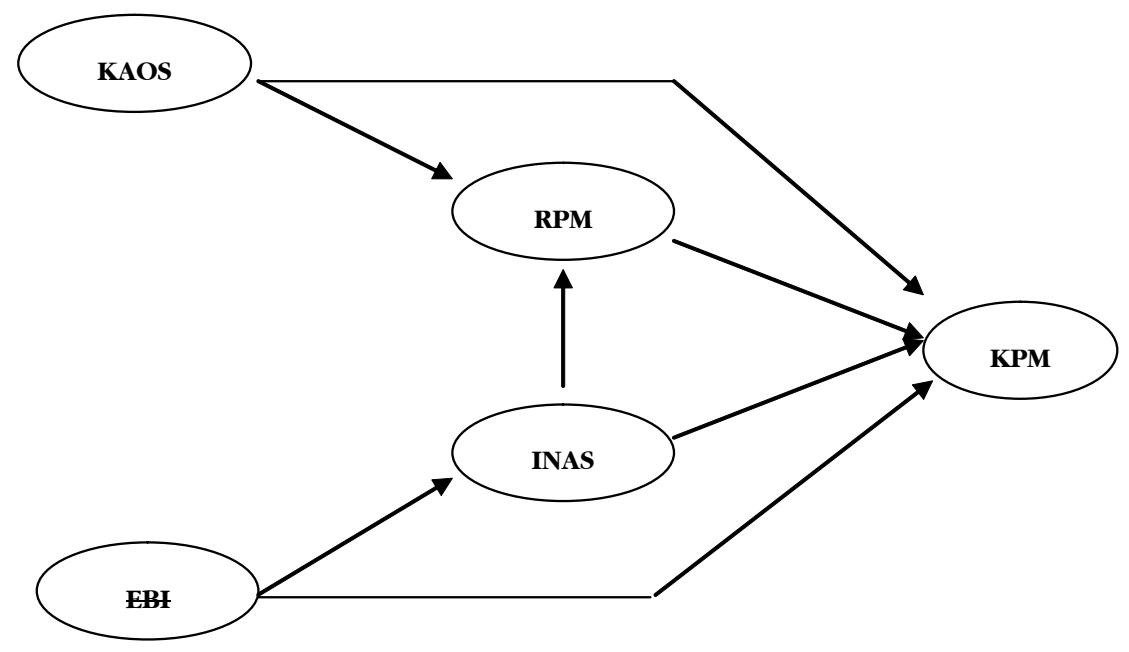

Gambar 1.

Model Penelitian Pengembangan Model Reduksi Resiko dan Eskalasi Kinerja Pembiayaan Mudharabah Pada Lembaga Keuangan Mikro Syari'ah

\section{Metode Peneltian}

\section{Jenis dan Sumber Data}

Penelitian ini tergolong jenis penelitian explanatory research karena tujuan penelitian adalah untuk menjelaskan hubunganhubungan dari variable-variabel melalui pengujian hipotesis yang telah dirumuskan.Penelitian ini menggunakan data primer dimana informasi atau data diperoleh berdasarkan pandangan, tanggapan, persepsi atau penilaian dari pimpinan dan/atau manajer pembiayaan mudharabah kantor cabang dan/atau kator pusat Lemaga Keuangan Mikro Syariah di kabupaten Jember dan Bondowoso terhadap variabel-variabel yang diteliti melalui kuesioner. Oleh karena itu penelitian ini termasuk penelitian persepsional (perception research) atau penelitian opini (opinion research). 
Populasidalam penelitian ini adalah seluruh LKMS yang ada di kabupaten Jember dan Bondowoso yang berjumlah 31 kantor, dengan dua responden yakni pimpinan dan/atau manajer pembiayaan mudahrabah pada setiap kantor. Teknik pengambilan sampel dalam penelitian ini menggunakan metode purposive sampling. Adapun kriteria pemilihan sampel adalah sebagai berikut:

1. Koperasi syariah/BMT pernah melaksanakan akad mudharabah.

2. Memiliki manajemen sendiri yang terpisah dari kantor pusat ataupun kantor cabang.

Instrumen utama yang digunakan dalam penelitian adalah kuesioner yaitu daftar pertanyaan yang terstruktur yang digunakan untuk mengukur penilaian responden dan fakta-fakta yang berhubungan dengan responden serta dengan keadaan yang telah diketahui responden dengan mengacu pada kuesioner penelitian dari Roziq 2007. Instrumen penelitian ditujukan kepada pimpinan kantor dan manajer pembiayaan mudharabah pada Lembaga Keuangan Mikro Syariah di Jember dan Bondowoso. Dari 31 sample dan 31 responden kuesioner berhasil kembali terkumpul semua.

Untuk menjamin validitas dan reliabilitas instrumen penelitian, maka dilakukan uji validitas dan reliabilitas instrumen. Uji validitas yang akan digunakan di dalam penelitian ini adalah validitas konstruk masing-masing item (indikator), dimana suatu item (indikator) dikatakan valid jika uji hipotesis terhadap loading factor positif dan bernilai $>0.7$ namun loading factor 0.5-0.6 dapat ditoleransi jika bersifat signifikan ( $\mathrm{p}$-value $<0,05$ ) dan mempunyai nilai T-statistik $>1.964$. Sedangkan uji reliabilitas yang digunakan dalam penelitian ini adalah composite reliability. Instrumen penelitian untuk mengukur sebuah variabel memiliki composite reliability yang baik jika memiliki composite reliability> 0.7 , walaupun bukan merupakan standar absolut.

\section{Teknik Analisis Data}

Penelitian ini menggunakan analisis kuantitatif untuk menjawab rumusan masalah. Analisis kuantitatif yang digunakan dalam penelitian ini terdiri dari analisis deskriptif untuk melihat gambaran karakteristik populasi dan analisis jalur. Analisis jalur 
digunakan untuk pengujian hipotesis dengan menggunakan Partial Least Squares (PLS). Ghozali (2006:19) menyatakan model formal PLS mendefinisikan variabel bentukan adalah linier agregat dari indikator-indikatornya. Estimasi terbobot yang dipergunakan untuk menciptakan komponen skor variabel didapat berdasarkan spesifikasi terhadap inner model dan outermodel.

Pengujian hipotesis dilakukan dengan melakukan langkahlangkah berikut. Pertama, untuk outer model dengan indikator reflektif dievaluasi berdasarkan pada konten substantifnya, yaitu dengan membandingkan besarnya bobot relatif dan melihat signifikansi bobot tersebut.

Kedua, inner model dievaluasi dengan melihat persentase varian yang dijelaskan yaitu dengan melihat nilai $\mathrm{R}^{2}$ untuk konstruk endogen dan juga melihat besarnya koefisien jalur struktural. Signifikansi pengaruh dievaluasi dengan menggunakan uji t-statistik. Perubahan nilai $\mathrm{R}^{2}$ dapat digunakan untuk menilai pengaruh variabel eksogen (independen) tertentu terhadap variabel dependen, yaitu apakah variabel tersebut berpengaruh substantif.

Metode analisis data dalam penelitian ini adalah Structural Equation Modeling menggunakan Partial Least Square(PLS) dengan bantuan program komputer paket SmartPLS, dengan alasan bahwa:

1. Model analisisnya berjenjang dan model persamaan structural memenuhi model rekursif;

2. Variabelnya laten;

3. Sample size-nya kecil dan tidak memenuhi untuk menggunakan SEM (structural equation model).

Adapun langkah-langkah di dalam analisis PLS(partial least square) adalah sebagai berikut : 1) merancang model struktural (inner model); 2) merancang model pengukuran (outer model); 3) mengkonstruksi diagran jalur; 4) konfirmasi diagram jalur ke sistem persamaan; 5) estimasi: koefisien jalur, loading dan weight; 6) evaluasi goodness of fit;7) pengujian hipotesis. 


\section{Analisis}

\section{Data Studi}

Dari total sampel yang diperkirakan adalah 31 obyek dan semua memenuhi kriteria sampel. Responden yang dapat dikonfirmasi hanya manajer dikarenakan sampel adalah kantor cabang pembantu dan kantor cabang sehingga bagian tertinggi dalam LKMS adalah manajer. Meskipun demikian sampel yang peneliti gunakan adalah sampel yang memiliki otorisasi pemberian keputusan kredit.

\section{Model Pengukuran atau Outer Model}

Pada pengukuran ini beberapa indicator variable di keluarkan dari model karena dianggap tidak cukup valid untuk mengkonstruk variabel.Dari hasil uji ini ternyata indikator yang layak untuk diuji adalah sebanyak 19 indikator yang tampak pada Gambar 2.

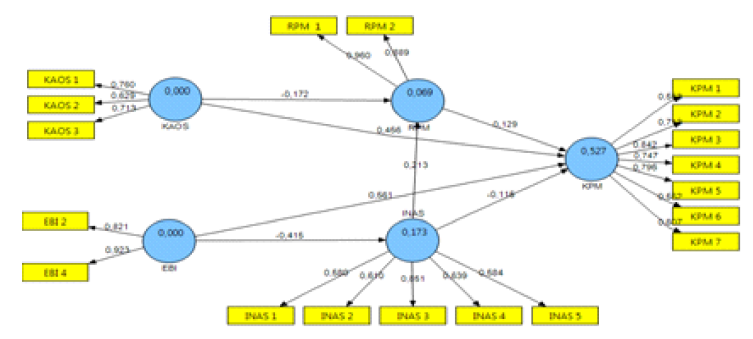

Gambar 2.

Hasil Output Grafik SMART- PLS Tahap II

Selanjutnya, dilakukan uji reabilitas dengan melihat cross loading, Jika korelasi konstruk dengan item pengukuran lebih besar daripada ukuran konstruk lainnya,maka hal ini menunjukkan bahwa konstruk laten memprediksi ukuran pada blok mereka lebih baik daripada ukuran pada blok lainnya. Hasil dari pengujian pada data penelitian ini menunujukkan validitas yang baik.Adapun tabel cross loading dapat dilihat pada tabel 2.Setelah mengkonfirmasi validitas indikator terhadap variabel, kemudian dilakukan uji reabilitas. Dengan melihat tabel composite reability.Instrumen penelitian untuk mengukur sebuah variabel memiliki composite reliability yang baik jika memiliki composite reliability e" 0.7.Hasil dari olah data dapat dilihat ditabel 
3.Semua konstruk memiliki nilai composite reliability lebih besar dari 0.70. Hal ini menunjukkan bahwa risiko pembiayaan mudharabah (RPM), kompetensi account officer syariah (KAOS), Etika Bisnis Islam (EBI), Asimetri Informasi (INAS) dan kinerja pembiayaan mudharabah (KPM) memiliki reliabilitas yang baik.

Tabel 2. Tabel Cross Loading

\begin{tabular}{llrrrr}
\hline & EBI & \multicolumn{1}{l}{ INAS } & \multicolumn{1}{c}{ KAOS } & \multicolumn{1}{c}{ KPM } & \multicolumn{1}{c}{ RPM } \\
\hline EBI 2 & 0,820651 & $-0,18603$ & $-0,0577$ & 0,460566 & $-0,184505$ \\
EBI 4 & 0,922728 & $-0,48779$ & $-0,0342$ & 0,527688 & $-0,081375$ \\
INAS 1 & $-0,11704$ & 0,579797 & $-0,06415$ & $-0,34445$ & $-0,063832$ \\
INAS 2 & $-0,12806$ & 0,609605 & 0,109947 & $-0,1866$ & $-0,17972$ \\
INAS 3 & $-0,45316$ & 0,850549 & 0,088154 & $-0,23194$ & 0,293968 \\
INAS 4 & $-0,32139$ & 0,639265 & 0,091645 & $-0,09521$ & 0,113853 \\
INAS 5 & $-0,07583$ & 0,584351 & 0,064019 & $-0,09022$ & 0,198748 \\
KAOS 1 & $-0,25666$ & 0,024489 & 0,759633 & 0,291795 & -0273009 \\
KAOS 2 & $-0,05502$ & 0,312567 & 0,629406 & 0,105976 & -0016217 \\
KAOS 3 & 0,238336 & 0,02746 & 0,71332 & 0,347657 & 0,053166 \\
KPM 1 & 0,116963 & $-0,36142$ & 0,282236 & 0,553364 & 0,09279 \\
KPM 2 & 0,640438 & $-0,25171$ & 0,095589 & 0,713285 & 0,091352 \\
KPM 3 & 0,505548 & $-0,18767$ & 0,351396 & 0,84218 & $-0,000609$ \\
KPM 4 & 0,444093 & $-0,04739$ & 0,342507 & 0,747473 & $-0,158446$ \\
KPM 5 & 0,421706 & $-0,15897$ & 0,348094 & 0,796057 & $-0,233694$ \\
KPM 6 & 0,213459 & 0,027866 & 0,15434 & 0,551566 & $-0,059186$ \\
KPM 7 & 0,208751 & $-0,38121$ & 0,371316 & 0,607352 & 0,074544 \\
RPM 1 & $-0,15089$ & 0,262286 & $-0,11098$ & $-0,0457$ & 0,959879 \\
RPM 2 & $-0,09601$ & 0,057588 & $-0,19501$ & $-0,02868$ & 0,888639 \\
\hline
\end{tabular}

Tabel 3. Compoite Realibility

\begin{tabular}{lr}
\hline & $\begin{array}{c}\text { Composite } \\
\text { Reliability }\end{array}$ \\
\hline EBI & 0,864815 \\
INAS & 0,790738 \\
KAOS & 0,744357 \\
KPM & 0,865082 \\
RPM & 0,92203 \\
\hline
\end{tabular}




\section{Model Struktural atau Inner Model}

Dalam penelitian ini, inner model atau model struktural dievaluasi dengan melihat melihat persentase variance yang dijelaskan melihat $\mathrm{R}^{2}$ untuk konstruk laten dependen dengan menggunakan ukuran Stone Geisser Q squarestest dan juga melihat besarnya koefisien jalur strukturalnya. Untuk uji goodness off fit dapat dilihat berdasarkan tabel 4. Kemudian dilakukan uji hipotesis, yang bertujuan menguji keterkaitan antar variable dalam penelitian yang dapat dilihat pada Tabel 5 berikut ini:

Tabel 4. R-Square

\begin{tabular}{lr}
\hline \multicolumn{2}{c}{ R Square } \\
\hline EBI & \\
INAS & 0,172572 \\
KAOS & \\
KPM & 0,527415 \\
RPM & 0,068546 \\
\hline
\end{tabular}

Tabel 5. Path Coeficients

\begin{tabular}{lrrrrr}
\hline & $\begin{array}{c}\text { Original } \\
\text { Sample (O) }\end{array}$ & $\begin{array}{c}\text { Sample } \\
\text { Mean (M) }\end{array}$ & $\begin{array}{c}\text { Standard } \\
\text { Deviation }\end{array}$ & $\begin{array}{c}\text { Standard } \\
\text { Error }\end{array}$ & $\begin{array}{c}\text { T Statistics } \\
\text { (IO/STERRI) }\end{array}$ \\
\hline $\mathrm{EBI} \rightarrow \mathrm{INAS}$ & $-0,415418$ & $-0,42159$ & 0,017471 & 0,017471 & 23,778107 \\
$\mathrm{EBI} \rightarrow \mathrm{KPM}$ & 0,560696 & 0,565357 & 0,026031 & 0,026031 & 21,539513 \\
$\mathrm{INAS} \rightarrow \mathrm{KPM}$ & $-0,114944$ & $-0,105303$ & 0,031108 & 0,031108 & 3,695023 \\
$\mathrm{INAS} \rightarrow \mathrm{RPM}$ & 0,213191 & 0,220215 & 0,038673 & 0,038673 & 5,512673 \\
$\mathrm{KAOS} \rightarrow \mathrm{KPM}$ & 0,456473 & 0,453865 & 0,017384 & 0,017384 & 26,257802 \\
$\mathrm{KAOS} \rightarrow \mathrm{RPM}$ & $-0,172086$ & $-0,168848$ & 0,041969 & 0,041969 & 4,100295 \\
$\mathrm{RPM} \rightarrow \mathrm{KPM}$ & 0,128765 & 0,125928 & 0,016018 & 0,016018 & 8,03852 \\
\hline
\end{tabular}

Dari tabel 5 di atas dapat disimpulkan dalam Tabulasi Hasil tabel 6 berikut ini:

Tabel 6. Tabulasi Hasil

\begin{tabular}{ll}
\hline Hubungan Indikator & Arah dan Signifikasi \\
\hline EBI -> INAS & Negatif Signifikan \\
EBI -> KPM & Positif Signifikan \\
INAS -> KPM & Negatif Signifikan \\
INAS -> RPM & Positif Signifikan \\
KAOS ->KPM & Positif Signifikan \\
KAOS ->RPM & Negatif Signifikan \\
RPM $->$ KPM & Positif Signifikan \\
\hline
\end{tabular}




\section{Kesimpulan}

Hasil penelitian ini mendukung teori keagenan yang menjelaskan bahwa ada problem/konflik keagenan antara pihak prinsipal dan pihak agen dalam produk pembiayaan mudharabah sehingga mempengaruhi capaian kinerja pembiayaan mudharabah.Hasil penelitian ini mendukung teori akuntansi positif yang menjelaskan bahwa ada masalah informasi asimetri antara pihak prinsipal dan pihak agen dalam produk pembiayaan mudharabah sehingga mempengaruhi risko pembiayaan mudharabah dan capaian kinerja pembiayaan mudharabah.Hasil penelitian ini mendukung teori enterprise syariah yang menjelaskan perlunya penerapan etika bisnis islami bagi pihak agen (mudharib) sehingga masalah informasi asimetri dan risiko pembiayaan mudharabah bisa diminimalisir sehingga kinerja pembiayaan mudharabah mampu ditingkatkan.

Hasil penelitian ini mendukung teori akuntansi syariah yang menjelaskan perlunya reformulasi kinerja secara komprehensif khususnya pada produk pembiayaan mudharabah dan umumnya pada lembaga keuangan mikro syariah dengan cara memasukkan nilai-nilai syariah/ spiritual sebagai bagian dari tujuan falah dalam indikator pengukuran kinerja lembaga/organisasi syariah seperti lembaga keuangan mikro syariah. Hasil penelitian ini mendukung teori kompetensi yang menjelaskan perlunya peningkatan kompetensi sumber daya manusia di perbankan syariah khususnya kompetensi account officer syariah yang menangani produk pembiayaan mudharabah sehingga mampu mendorong mereka bersungguh-sungguh dalam melaksanakan tanggungjawab sehingga melahirkan kinerja yang terbaik.

Secara teoritis nampak bahwa pembiayaan mudharabah merupakan produk yang sangat ideal bagi kedua belah pihak (bank dan mudharib). Namun dalam prakteknya sulit diterapkan karena ia membutuhkan kondisi yang ideal seperti kompetensi account officer syariah yang tinggi, tidak adanya (rendahnya) informasi asimetri serta membutuhkan mudharib yang memiliki etika bisnis islami yang tinggi. Bisa disimpulkan bahwa produk pembiayaan mudharabah merupakan pembiayaan yang sangat ideal namun sekaligus sulit diterapkan.

Banyaknya kendala yang dihadapi lembaga keuangan mikro syariah (unit usaha syariah) menyebabkan pembiayaan mudharabah 
yang menggunakan sistem profit sharing tidak bisa dijalankan secara menyeluruh/sempurna atau secara kafah. Banyaknya kendala yang ada berdampak pada pilihan pembiayaan yang dilakukan oleh manajemen lembaga keuangan mikro syariah (unit usaha syariah) lebih difokuskan pada pembiayaan dengan sistem non bagi hasil ( $n o n$ profit and loss sharing) seperti pembiayaan murabahah. Meskipun pembiayaan mudharabah ada dan dalam jumlah kecil di jalankan oleh manajemen lembaga keuangan mikro syariah (unit usaha syariah) namun sistem bagi hasil yang digunakan adalah revenue sharing walaupun ada yang menggunakan sistem profit sharing dalam jumlah kecil. Idealnya penggunaan sistem bagi hasil yang lebih mendekati pada prinsip ekonomi Islami (kafah) yaitu keadilan adalah sistem profit sharing namun sistem ini agak sulit diterapkan karena membutuhkan kondisi yang ideal (kafah) yang berkaitan dengan perilaku mudharib dan administari laporan keuangan. Buruknya perilaku mudharib serta buruknya administrasi laporan keuangan menyebabkan manajemen lembaga keuangan mikro syariah (unit usaha syariah) di Jember dan Bondowoso lebih memilih menggunakan revenue sharing sehingga lebih memudahkan pelaksanaan operasionalisasi pembiayaan mudharabah daripada sistem profit sharing meskipun sistem ini lebih ideal dan adil (kafah) namun sulit diterapkan.

Manajemen lembaga keuangan mikro syariah harus melakukan tindakan untuk meningkatkan kinerja pembiayaan mudharabah terutama yang berkaitan dengan peningkatan pertumbuhan pembiayaan mudharabah, peningkatan pertumbuhan mudharib dan peningkatan kontribusi zakat. Namun demikian manajemen masih perlu melakukan tindakan untuk meningkatkan kinerja pembiayaan mudharabah melalui manajemen pembiayaan mudharabah terhindar dari riba, gharar dan maisyir, peningkatan kontribusi terhadap mudharib dan peningkatan tingkat keuntungan. Manajemen lembaga keuangan mikro syariah hendaknya tidak hanya menekankan capaian kinerja pembiayaan mudharabah hanya pada hasil semata namun hendaknya juga menilai pada proses dan kontribusinya pada stakeholders.

Para mudharib yang mendapatkan pembiayaan mudharabah perlu meningkatkan etika bisnis islami terutama yang berkaitan dengan shidiq, istiqomah dan tabligh. Dengan peningkatan nilai shidiq bagi para mudharib maka ketentuan-ketentuan kontrak pembiayaan 
mudharabah akan mudah ditaati dan dipenuhi. Nilai istiqomah bagi para mudharib perlu ditingkatkan agar supaya para mudharib mampu menjalankan bisnisnya dengan sabar, teguh dan ulet sehingga sukses. Dengan peningkatan nilai tabligh maka para mudharib lebih transparan (terbuka) dalam menyampaikan laporan keuangan bisnisnya.

Bank Indonesia akan memberikan kebijakan dalam rangka meningkatkan kinerja lembaga keuangan mikro syariah bisa dilakukan dengan cara directed market driven dengan menetapkan target/capaian persentase tertentu porsi pembiayaan mudharabah dan musyarakah dan kebijakan pengawasan syariah terhadap setiap praktek pembiayaan mudharabah perlu dijalankan agar tidak menyimpang dari kaidah-kaidah syariah.

Kesimpulan secara keseluruhan memperlihatkan bahwa kompetensi account officer syariah dan informasi asimetri berpengaruh signifikan terhadap risiko pembiayaan mudharabah. Etika bisnis Islami berpengaruh signifikan terhadap informasi asimetri. Kompetensi account officer syariah dan informasi asimetri berpengaruh signifikan terhadap kinerja pembiayaan mudharabah.

\section{Daftar Pustaka}

Abdurahman, Yusuf dan Unti Ludigdo. 2004. Dekonstruksi Nilai-Nilai Agency Theory Dengan Nilai-Nilai Syari'ah: Suatu Upaya Membangun Prinsip-Prinsip Akuntansi Yang Bernafaskan Islam. Prosiding Simposium Nasional Sistem Ekonomi Islam II:249-262. Unibraw. Malang. Abdelhamid, Mohamed. 2005. Islamic Banking.Paper:1-75. Ottawa Ontario: Department of Economics Carleton University. http:// www.nzibo.com/ Diakses tanggal 3 Maret 2012

Andrew, Barenberg. 2004. Islamic Financing Impacts on Development and Equality.Oeconomicus Journal: volume VII. University of Missouri Kansas City.

Bank Indonesia. 2000. Potensi, Preferensi dan Perilaku Masyarakat Terhadap Bank Syari'ah: Studi Pada Wilayah Jawa Timur. http:// www.bi.go.id./Diakses tanggal 7 Maret 2012.

Elgari, Mohamed Ali. 2003. Credit Risk in Islamic Banking and Finance. Journal of Islamic Economic Studies 10(2):1-25.

Ghazali, Imam. 2007. Structural Equation Modeling Metode Alternatif Dengan Partial Least Square. Badan Penerbit Universitas Diponegoro. Semarang. 
Gizycki, Marianne. 2001. The Effect of Macroeconomic Conditions on Banks Risk and Profitability Sistem Stability.Discussion Paper. Department Reserve Bank of Australia Research.

Harri, Milton and Arthur Raviv. 1990. Capital Structure and Informational Role of Debt. Journal of Finance 45:321-349.

Ibrahim, Maulana. 2004. Risk Management: Islamic Financial Policies : Case Study of Bank Indonesia. http://www.bi.go.id. Diakses tanggal 5 Maret 2012.

Ismail, Mazlan. 2005. The Influence of Intellectual Capital on the Performance of Telekom. Malaysia: Universiti Teknologi Malaysia. http//www.eprints.utm.my// Diakses tanggal 2 Maret 2012

Jensen, Michael C and William Meckling H.. 1976. Theory of the Firm: Managerial Behavior, Agency Costs and Ownership Structure. Journal of Financial Economics 3(4):305-360. Harvard Business School.

Joseph, Heath. 2004. An Adversarial Ethic for Business. Article Type: Philosophical Foundations:1-38. Department of Philosophy University of Toronto.

Karim, Adiwarman. 2004. Bank Islam: Analisis Fiqih dan Keuangan. Edisi Kedua. PT. Raja Grafindo Persada. Jakarta.

Larry L, Axline. 1990. The Bottom Line on Ethics; a Fresh Perspective on a Worthwhile Subject. Journal of Accountancy Vol:170. Trusted Online Research, Questia.

Rusyani, Erni. 2004. Budayakan Etika Bisnis. Bandung: Pikiran Rakyat Online Roziq, Ahmad. 2007. Pengaruh Kompetensi Account Officier Syariah Dan Etika Bisnis Islam Terhadap Kinerja Pembiayaan Mudharabah Melalui Informasi Asimetri Serta Resiko Pembiayaan Mudharabah Pada Bank Syari'ah Di Jawa Timur. Disertasi. Fakultas Ekonomi Universitas Airlangga, Surabaya.

Samad, Abdus, and M. Hassan Kabir. 1999. The Performance of Malaysian Islamic Bank During 1984-1997: an Exploratory Study. International Journal of Islamic Financial Services 1(3):1-12.

Sugiarto, Agus. 2004. Mengapa Manajer Risiko Bank Harus Disertifikasi. Kompas Online.

Siddiqui, Shahid Hasan. 2005. True Modes of Financing. Kuwait: Islamic Banking htm.

Scott, William R.. 2006. Financial Accounting Theory. Fourth Edition. Toronto USA: Prentisce Hall.

Warjiyo, Tarsidin Perry. 2003. Perbankan Syariah dan Perbankan Berdasarkan Bunga: Manakah Yang Lebih Optimal. Info Bank News.com 